\title{
O PRINCÍPIO RESPONSABILIDADE E A ENGENHARIA GENÉTICA
}

The imperative of responsibility and the genetic engineering

Marijane Lisboa

RESUMO: À época em que Hans Jonas desenvolveu sua reflexão sobre a Ética necessária a uma era tecnológica, as plantas transgênicas ainda não eram uma realidade. Pouco tempo depois da sua morte, no entanto, já se plantavam soja, milho, canola e algodão transgênicos em todos os continentes, alimentos que daí em diante farão parte da dieta global, animal e humana. Embora promovida e defendida pelas grandes corporações internacionais de biotecnologia e pelos países líderes no terreno da inovação tecnológica e patenteamento, cientistas, filósofos e segmentos da sociedade civil em todo o mundo manifestaram fortes restrições à liberação de plantas transgênicas no meio ambiente e na alimentação humana e animal. Além de desnecessária, a engenharia genética é uma tecnologia demasiadamente nova cujos efeitos colaterais são imprevisíveis e caso negativos, irreversíveis, tanto no que se refira à agrobiodiversidade, quanto à saúde humana e animal. Por isso, ainda que Hans Jonas não tenha tido a oportunidade de refletir especificamente sobre essa tecnologia, deveríamos recorrer ao seu Princípio Responsabilidade como fundamento ético do Princípio da Precaução, uma vez que se trata de preservar as condições necessárias à continuidade da espécie no planeta.

PALAVRAS-CHAVE: Princípio Responsabilidade; Engenharia Genética; Princípio da Precaução.

Em primeiro lugar desejo agradecer imensamente aos organizadores do II Seminário Hans Jonas da UFRJ pelo convite para proferir a primeira conferência deste evento, ao mesmo tempo que manifestar mais uma vez o temor de que não esteja à altura de tão honroso convite. Sou socióloga, e não filósofa, e meu vínculo com a filosofia de Hans Jonas estabeleceu-se em uma trajetória absolutamente distinta da maioria dos participantes deste seminário.

Fui durante quase dez anos membro do Greenpeace Brasil onde fui responsável por campanhas contra substâncias químicas e tecnologias perigosas como agrotóxicos, incineradores e fábricas de cloro entre outras. Finalmente, nos dois últimos anos da minha atuação no Greenpeace, me encarregaram da campanha contra transgênicos. Tendo que ao mesmo tempo fazer uma tese de doutorado na PUC-SP onde leciono, escolhi um tema afim com minha 
militância ecológica, ou seja, o comércio mundial de resíduos perigosos ${ }^{1}$. Em toda esse campo técnico que lida com substâncias tóxicas, a grande discussão é sempre se há evidências científicas suficientes de que certas substâncias sejam efetivamente tóxicas ou haveria apenas indícios, que não poderiam ser cientificamente comprovados, nem tampouco descartados. Algumas destas substâncias que no passado se acreditava não tóxicas ou moderadamente tóxicas, contudo, como os inseticidas DDT, se revelaram posteriormente cancerígenas, mutagênicas e perturbadoras do sistema endócrino entre outros efeitos colaterais, gerando em muitos casos danos irreversíveis à saúde humana. Por isso, surgiu na legislação ambiental uma abordagem de precaução, ou de prudência, com se queira chamar. Resumidamente, em dúvida quanto a potenciais danos de certas tecnologias ou produtos, decida-se por uma atitude de proteção à saúde e ao meio ambiente.

Como averiguei em minha tese, o Princípio da Precancão surgiu mais ou menos na mesma época, na legislação ambiental da Suécia e da Alemanha. Ele basicamente estabelece que autoridades não devem alegar ausência de evidências científicas para se furtar a adotar medidas de precaução quando há indícios de que determinadas atividades possam trazer danos sérios aos seres humanos e ao meio ambiente. Atividades que poderiam causar grandes danos, ou que estes eventuais danos pudessem ser irreversíveis ou seus impactos imprevisíveis, deveriam ser evitadas. Inicialmente tornado leis nesses dois países, mais tarde o Princípio da Precaução será um princípio fundamental do direito ambiental, do direito à saúde e também da proteção ao patrimônio histórico entre outros.

Foi assim que cheguei a Jonas. Alguns colegas do Greenpeace da Alemanha, sabendo que eu lia alemão, me presentearam com um exemplar do Das Prinzip Verantwortung, editado pela Suhrkamp². Ao lê-lo, percebi a clara vinculação entre o Princípio Responsabilidade e o Princípio da Precaução, pois o primeiro parecia fornecer a fundamentação filosófica, moral, para o segundo.

O Princípio da Precaução, por outro lado, parecia elucidar as condições e circunstâncias em que o Princípio Responsabilidade de Jonas deveria ser aplicado, condições e circunstâncias essas que o filósofo apenas delineia ao tratar de algumas daquelas limitações em pesquisa científica e desenvolvimento científico cujos "objetivos e meios seriam eticamente recusáveis". Escrevi então um artigo sobre a relação entre os dois princípios que saiu na revista Margem, da Faculdade de Ciências Sociais, há algum tempo atrás ${ }^{3}$.

\footnotetext{
Minha tese será mais tarde publicada pela Civilização Brasileira: Ética e Cidadania Planetárias na Era Tecnológica: o caso da Proibição da Basileia. Civilização Brasileira, RJ, 2009.

2 Hans Jonas, Das Prinæip Verantwortung: Versuch einer Ethik für die technologische Zivilisation, Suhrkamp taschenbuch, Frankfurt am Main, 1993.

3 Lisboa, M. O fundamento ético do Princípio da Precaução, Margem, São Paulo, nº21, pags.77a 91, Junho de 2005.
} 
Alguns anos depois, a Editora Contraponto, para quem eventualmente traduzo do alemão, me pediu para fazer a revisão da tradução do Princípio Responsabilidade de Hans Jonas, e logo em seguida para que eu continuasse a tradução da obra, já que o primeiro tradutor havia desistido de continuá-la. Finalmente, há quase dois anos atrás, ao ser convidada para a banca de uma tese no Programa de Filosofia da PUC-SP, tive oportunidade de conhecer os professores Jelson Roberto de Oliveira e Helder de Carvalho, que em seguida me convidaram para ingressar no grupo de trabalho Hans Jonas da ANPOF e também para participar do Colóquio Hans Jonas em Teresina, entre 18 e 20 de novembro do ano passado.

Quando escolhi o tema da minha palestra naquele Colóquio, pensei que o melhor que poderia fazer como socióloga em um evento de filósofos seria mostrar como a filosofia de Hans Jonas pode ser útil aos filósofos e também aos não filósofos para orientar-se em meio a questões atuais da política ambiental, ajudando-nos a pensar os desafios éticos dessa política. Assim, peço que me perdoem aqueles colegas que assistiram à minha palestra em Teresina, porque vou repetila em grande parte.

\section{Por que Engenharia Genética?}

Esse é um dos temas com os quais tenho lidado há mais de 10 anos de modo sistemático, desde o período em que atuei no Greenpeace até os dias de hoje. Mesmo depois que saí dessa organização, o tema dos transgênicos não me abandonou e acredito que ao expô-lo também vou conquistar alguns corações e mentes para ele entre vocês. Passei quatro anos representando os consumidores em uma comissão, a Comissão Técnica Nacional de Biossegurança - CTNBio, que é encarregada no Brasil da política referente à engenharia genética. Concluí no começo desse ano o segundo mandato de dois anos e ainda que tenha sido uma experiência muito frustrante por razões que exporei mais adiante, foi uma campo fertilíssimo para mostrar como é possível que cientistas e autoridades públicas ignorem esses dois princípios que estão tão integralmente relacionados: o Princípio Responsabilidade e o Princípio da Precaução.

Curiosamente, a questão da aplicação de tecnologias modernas às plantas é uma das questões para as quais Jonas acredita que se possa arcar com riscos do desenvolvimento tecnológico. Assim, na longa entrevista ou debate transcrita ao fim do livro Técnica, Medicina e Ética, editada pela Paulus e traduzida pelo Grupo de Trabalho Hans Jonas da ANPOF ${ }^{4}$, Jonas, na página 318, afirma que embora se conheçam os inconvenientes perigosos do emprego de aditivos químicos para aumentar o rendimento das plantas, estes deveriam ser permitidos até que

4 Hans Jonas, Técnica, Medicina e Ética: sobre a prática do princípio da responsabilidade, Paulus, SP, 2013. 
se encontrasse soluções mais adequadas e que se eliminasse a necessidade de aumentar o rendimento das plantas, ou seja, até que se eliminasse a fome sobre a Terra e a produção deficiente em certas regiões, como é o caso do Terceiro Mundo.

Então, nessa minha conferência, irei discordar de Jonas - espero que me perdoem - mas mostrarei que embora ele se equivoque na questão empírica, o que é natural tratando-se de um filósofo - seu Princípio Responsabilidade continua sendo o princípio mais adequado também para lidar com os experimentos e com os novos "objetos" criados pela engenharia genética. Ou seja, que malgré lui, ele está certo, ou apesar de ter se equivocado, continua certo.

Comecemos, portanto, pelo que sejam transgênicos. Podem sem animais, mas nos dias de hoje são sobretudo plantas nas quais se inseriram genes de outras plantas, insetos, vírus ou bactérias de modo que elas apresentem propriedades que elas não tinham anteriormente. Dado que seres vivos, e animais e plantas em particular só transferem material genético verticalmente, ou seja de uma geração para outra, a engenharia genética faz algo que até então era desconhecido na Natureza, ou seja, a troca de material genético horizontalmente.

A soja transgênica Roundup Ready ${ }^{5}$, por exemplo, tem um gene de uma planta que é tolerante a um determinado agrotóxico. Outros genes também são enxertados em seu DNA para que aquele gene desejado penetre efetivamente nesse DNA e permaneça ativo nas gerações seguintes. Também se produziu um milho transgênico no qual se inseriu o gene de uma bactéria muito comum no solo, que secreta uma toxina que mata certos insetos que atacam o milho ${ }^{6}$. Em nenhum desses casos, portanto, como Jonas julgou erroneamente, assistimos a um aumento do rendimento ou da produtividade agrícola. Temos apenas plantas sobre as quais pode-se jogar grande quantidade de agrotóxicos sem que morram, ou outras que contêm elas mesmas, em seus grãos e folhagem, agrotóxicos que matam as pragas que as atacam.

Mas a que se referia Jonas ao falar de tecnologias que aumentam a produtividade apesar de seus inconvenientes? Certamente não a transgênicos, que àquela época, 1984, ainda não existiam em escala comercial. Ao se referir a "aditivos químicos", provavelmente estaria considerando o emprego intensivo de em fertilizantes e agrotóxicos, além da técnica de irrigação consumidora de energia, que ele menciona explicitamente nessa passagem.

Ora, esse pacote tecnológico composto de irrigação, uso de fertilizantes e agrotóxicos, seleção de sementes e mecanização da agricultura acabou por receber o nome bastante impróprio de Revolução Verde. Aplicado no mundo todo a partir dos anos 40, ele revolucionou a agricultura,

5 A Soja RR foi a primeira planta transgênica introduzida comercialmente no mundo, produzida pela transnacional estadunidense Monsanto.

6 O Bacilus Turingensis, conhecido dos agricultores orgânicos e utilizado nos casos bastante raros de infestação de pragas, por meio de uma calda. 
transformando-a num grande negócio de dimensões nacionais e internacionais. A produção de grãos aumentou exponencialmente e o seu preço caiu, embora não se possa dizer o mesmo da produtividade. Por hectare, por uso de recursos naturais como terra, água, conservação de diversidade agrícola e ecológica, o agronegócio nunca foi nem é mais produtivo que o seu modesto antepassado, a agricultura camponesa ${ }^{7}$.

Praticada em pequena escala, a agricultura camponesa em qualquer de suas muitas tradições culturais - europeias, de povos indígenas americanos, africanas, chinesas, indianas e japonesa - sempre foi mais produtiva, pois soube aproveitar melhor os recursos naturais - terra, água, biodiversidade e força de trabalho - sem degradá-los por meio do uso intensivo de fertilizantes, agrotóxicos, irrigação, compactação do solo por mecanização, gasto com combustíveis fósseis e emissão de gases de efeito estufa, entre outros aspectos. Simplesmente não se pode ganhar muito dinheiro com ela. De modo a não se expor o solo às intempéries, ocasião em que se perde seu material nutritivo, não se pode cultivar grandes extensões da mesma planta, proceder à colheita em um só momento e se deixar o solo nu, exposto ao sol e a chuvas. A irrigação constante pode trazer salinização e apodrecimento das raízes e associada aos agrotóxicos, contaminar o solo, matar a microfauna, os insetos benéficos à agricultura, contaminar o lençol freático, intoxicar animais e seres humanos que bebem essa água. Não preciso certamente mencionar os danos para a nossa saúde que advêm do consumo de plantas sobre as quais se jogou grande quantidade de agrotóxicos.

A lógica comercial do agronegócio leva também a abandonar variedades de plantas que são mais difíceis de transportar, conservar ou menos requeridas pelos mercados, fazendo com que hoje em dia tenhamos perdido grande parte das variedades de arroz, trigo, milho e feijão que eram cultivadas até o começo do século passado.

Finalmente não devemos nos esquecer que o agronegócio requer grandes extensões de terras e dado o fato de que ele degrada o solo e exaure os recursos hídricos, tende a avançar e devorar novas terras ainda não cultivadas que encontre à sua frente, sendo esta a causa do interminável desmatamento do Cerrado brasileiro, da Floresta Amazônica e do que resta da Mata Atlântica.

Assim, a razão da Revolução Verde não foi o generoso objetivo de alimentar os famintos da Terra, mas o de tornar o alimento uma commodity, produzida em massa, vendida em massa, consumida em massa pelo mercado mundial de alimentos. E enganou-se Jonas, também, ao crer que o Terceiro Mundo passasse fome porque sua produção agrícola fosse deficiente ou

7 A respeito da agricultura camponesa: Alier, Joán Martinez, Da Economia Ecológica ao Ecologismo Popular, Editora da FURB, Blumenau, 1998;Carvalho, Horácio Martins de, O Campesinato no Século XXI, Editora Vozes, Petrópolis, 2005; Petersen, Paulo (org.) A Agricultura Familiar Camponesa na Construção do Futuro, AS-PTA< RJ, 2009; Shiva, Vandana, Monoculturas da Mente:perspectivas da biodiversidade da biotecnologia, Editora Gaia, SP, 2003. 
demasiado cara. Passa-se fome porque roubou-se as terras de boa parte da nossa população indígena que conseguiu sobreviver ao extermínio dos primeiros tempos; porque libertou-se os escravos, mas não se lhes deu terras e porque, continuamente, rouba-se as terras dos camponeses brasileiros, que quando as tem, tem pouca, minifúndios, e frequentemente as mais áridas. $\mathrm{O}$ campesinato familiar tampouco tem crédito rural fácil, isenções de impostos e financiamento de equipamentos, tudo o que sobra para o agronegócio brasileiro, por exemplo. Mas, mesmo assim, o campesinato familiar faz milagres, pois é responsável por boa parte dos alimentos que consumimos.

Fosse a agricultura indígena do Terceiro Mundo pouco produtiva, e os europeus não teriam encontrado nas Américas uma população superior a 50 milhões de pessoas segundo estimativas dos especialistas, bem nutridas e com aparência invejável se comparada a eles. Mas, entre pestes, trabalho escravo nas minas e roubo de suas terras, hoje sobrevive apenas uma parte mínima desses indígenas ${ }^{8}$. O mesmo podemos dizer das enormes populações agrárias da Ásia e África, que desconheceram a fome até a chegada dos europeus. Expulsos de suas terras pelo imperialismo europeu, uma enorme massa despossuída se concentrou em suas cidades e à essa massa é que falta trabalho e dinheiro para comprar comida. As estatísticas internacionais mostram que o planeta hoje produz mais alimentos do que o suficiente para alimentar decentemente sua população. O problema da fome não é um problema de volume de produção, mas de distribuição desigual de recursos para ter acesso aos alimentos: terra e renda. Enfim, um problema social.

Dito isso em discordância com Jonas, ainda tenho bastante a dizer sobre essa neta da Revolução Verde que é a Engenharia Genética. Como já disse antes, a grande maioria dos transgênicos até hoje "inventados", tem como objetivo permitir que o agronegócio use maior quantidade de agrotóxicos em plantas a eles tolerantes, matando as chamadas ervas invasoras, ou eliminar a necessidade de aplicação de agrotóxicos, ao transformar as próprias plantas em agrotóxicos. A economia de recursos na aplicação de agrotóxicos redunda, portanto, em maior consumo de agrotóxicos de nossa parte. Não foi à toa que depois da adoção da soja e milho transgênicos no Brasil nos tornamos seus maiores consumidores, ultrapassando os EUA nesse aspecto. Agricultores interessados em vender seus alimentos independentemente de sua qualidade, vem nisso um bom negócio, pois com poucas fumigações de um mesmo agrotóxico, economizam em aplicações sucessivas e mão de obra. Empresas de biotecnologia, a maioria transnacionais - Monsanto, Singenta, Bayer, Basf e Du Pont entre as maiores - são na verdade as

8 Sobre a catástrofe demográfica que aniquilou grande parte da população pré-colombiana ver: Crosby, A., Imperialismo Ecológico, Companhia das Letras, SP, 1993; Diamond, J., Armas, Germes e Aço:os destinos das sociedades bumanas, Record, RJ, 2001; Rouland, N., Direito das minorias e dos povos autóctones, Editora UNB, Brasília, 2004. 
que mais ganham com a venda de sementes transgênicas e os agrotóxicos a elas associados. Patenteando suas plantas transgênicas, fidelizam à força os produtores rurais, que passam a ter que comprar suas sementes todas as vezes que plantam, pois o retorno à agricultura convencional é difícil, senão impossível, dada a contaminação das variedades convencionais pelas transgênicas. As indústrias químicas também ganham, portanto, bem como as indústrias de máquinas. A Revolução Verde é assim um excelente negócio, menos para a humanidade e para o meio ambiente.

Uma pequena lista dos danos irreversíveis que a transgenia pode causar?

As plantas "engenheiradas" podem trocar material genético com suas parentas, chamadas convencionais e na seleção natural podem se sair melhor e eliminar a existência dessas últimas. Não é possível saber o que acontecerá em cada caso e em cada ecossistema. O experimento está sendo feito em tempo real e em escala sem procedentes. Se isso acontecer, perderemos variedades de plantas que nossos camponeses e populações indígenas levaram milênios para domesticar e adequar à alimentação humana e animal. E, como sabemos, somos capazes de destruir a Natureza, mas não de criá-la.

As plantas transgênicas ou os agrotóxicos a elas associados podem matar abelhas, pássaros, mariposas, borboletas e causar grandes danos aos ecossistemas nos quais esses insetos e animais cumprem um papel fundamental. Sem tais insetos, é possível que tenhamos quebras de safra monstruosas e grandes fomes. Boa parte das plantas com as quais nos alimentamos são fertilizadas por esses insetos e animais.

A inserção genética em organismos estranhos a eles pode produzir proteínas desconhecidas que podem gerar enfermidades também desconhecidas em nós e nos animais ou intensificar aquelas enfermidades que já conhecemos como alergias, mutações genéticas, cânceres. É possível que levemos décadas para descobri-lo e talvez mais ainda outras décadas, para combatê-las.

Finalmente, plantas são serem vivos, se reproduzem naturalmente. Uma vez liberadas no meio ambiente, plantas transgênicas não são passíveis de recall. Por isso, dizemos que plantas transgênicas oferecem riscos imprevisíveis e em grande parte irreversíveis, além de serem desnecessárias. Os sistemas agroecológicos, que são a combinação dos conhecimentos milenares de nossos agricultores com a moderna ciência agroecológica, são perfeitamente capazes de alimentar o mundo, caso recebam os mesmos estímulos e recursos destinados ao agronegócio. Diz-se comumente que a agricultura orgânica seria incapaz de alimentar o mundo, o que não é

9 Sobre a discussão a respeito de benefícios e riscos de transgênicos: Andrioli, A.I. e Fuchs R., (Orgs.) Transgênicos: As Sementes do Mal: a silenciosa contaminação de solos e alimentos, Expressão Popular, SP, 2008; Lacey, Hugh, $A$ Controvérsia sobre os Transgênicos, Ideias e Letras, Aparecida, 2006; Zanoni, M., e Ferment, G., Transgênicos para quem? Agricultura Ciência e Sociedade, MDA, Brasília, 2011. 
verdade. O agronegócio que recorre a alta tecnologia só produz mais, porque é ajudado a produzir. Olhemos para nós, no Brasil. Grandes produtores de soja, milho, cana-de-açúcar e de carne de vaca, aves e porcos, que exportamos - consumimos o arroz, feijão, milho, mandioca, verduras e frutas - produzidos fundamentalmente pela agricultura familiar, que enfrenta enormes dificuldades por não encontrar crédito público suficiente e não ter as suas dívidas periodicamente perdoadas, como acontece com os seus grandes concorrentes.

Bem, retornando a Jonas: se as tecnologias da Revolução Verde não são a solução para a fome, e se ao contrário, ela e a Engenharia Genética são elas mesmas grandes ameaça à segurança alimentar da humanidade devido à degradação do solo, contaminação das águas, perda de biodiversidade agrícola e desperdício de energia fóssil que requerem - e se somamos a isso as mudanças climáticas que aí estão e que certamente aumentarão as regiões sujeitas a um crescente estresse hídrico - então, seguindo o raciocínio de Jonas, também a Engenharia Genética e o pacote tecnológico da Revolução Verde não deveriam ser estimuladas, nem permitidas.

E aqui não se trata apenas de pesquisa e experimento científico que siga caprichos e não necessidades humanas que podem ser consideradas como éticas, casos em que Jonas considera que não se deva permitir experimentos com seres vivos. $O$ objetivo da transgenia agrícola é meramente o lucro, cabendo seus benefícios a apenas um punhado de empresas, grandes agricultores e beneficiadores de alimentos, enquanto seus danos recaem sobre a humanidade e o meio ambiente nessa e em futuras gerações.

E aí encontramos Jonas novamente. Que direito temos de ameaçar a saúde diretamente e indiretamente a sobrevivência da humanidade, comprometendo um patrimônio da biodiversidade agrícola que todos os povos que vieram antes de nós, desde que se tornaram sociedades agrícolas, desenvolveram e preservaram para nós? Foram eles os verdadeiros cientistas, os que selecionaram plantas individuais mais suculentas, mais nutritivas, mais doces e por meio de cruzamentos durante milênios as legaram a nós. Se a bumanidade deverá existir - e creio que esse é um mandamento que a Ética nos impõe - deverá ela sucumbir lentamente por fome e desnutrição em meio a guerras civis e guerras entre países pelas poucas terras férteis que restarão? Ou, na melhor das distopias cientificas, sobreviver comendo pílulas de concentrados químicos, distribuídas por sabemos lá que tecnocracia governante, sem o direito de comer como nós, alimentos saudáveis, variados, gostosos e nutritivos?

Se respondemos positivamente a essa pergunta, a la Jonas, então não podemos chamar o que ocorre nos nossos órgãos registradores de transgênicos no Brasil, como a Comissão Técnica Nacional de Biossegurança-CTNBio ${ }^{10}$, mas também em outros de muitos países, como os da

10 Glass, V., A Ciência Segundo a CTNBio, Revista Sem Terra, ed.54, nov/dez. 2009; Marinho, C.L,C e Minayo- 
União Europeia, da Argentina ou dos EUA, de uma conduta ética.

De fato, embora o Princípio da Precaução conste do Protocolo de Cartagena, o princípio que advoga justamente uma atitude de prudência frente às novas tecnologias, e que o Protocolo que pertence à Convenção sobre Diversidade Biológica tenha sido assinado por uma grande parte dos países membros do sistema ONU como princípio norteador das suas decisões, todas as autorizações para o plantio comercial e o consumo humano e animal de plantas transgênicas dadas em países como os EUA, Argentina, Canadá, Espanha e vários outros, não o respeitam.

Além disso, embora haja razoáveis diferenças nas legislações dos diversos países quanto aos trâmites legais a que são submetidos os pedidos de liberação de transgênicos no meio ambiente e para a alimentação humana e animal, esses trâmites exigem muito pouco no que concerne à pesquisa sobre possíveis efeitos colaterais. O ponto de partida desses processos não é o resultado de pesquisas independentes que trazem melhorias para os eventuais problemas da produção agrícola atual, mas a solicitação de liberação dos seus "produtos" desenvolvidos nos seus departamentos de pesquisa por parte transnacionais da biotecnologia aos órgãos responsáveis, em geral, primeiramente nos EUA, depois na Argentina e em seguida no Brasil, aí então arriscando-se uma autorização na União Europeia.

As análises de risco são feitas, portanto, pelas próprias empresas e os órgãos fiscalizadores apenas conferem se tais estudos seguem os protocolos estabelecidos e se chegam à conclusão sobre a inocuidade dos seus "produtos". Tais protocolos, por sua vez, resumem-se a alguns poucos estudos, bastante básicos, estudando-se a toxicidade aguda para ratos durante um curto período e comparando-se as novas toxinas produzidas com as existentes e já conhecidas.

É preciso dizer que nenhum transgênico até hoje foi rejeitado por um desses órgãos e por isso, até hoje, todos os transgênicos desenvolvidos, foram em seguida liberados para uso comercial e consumo humano e animal. Por isso, temos várias sojas e muitos milhos transgênicos que fazem hoje parte da nossa alimentação diária, bem como da ração dos animais. Não se pesquisa, nem se exige que se pesquise a toxicidade crônica; não se examinam efeitos adversos em animais prenhes e não se testam os alimentos transgênicos em pelo menos dois mamíferos, como já hoje se faz em relação a remédios. Pior que isso, move-se uma campanha publicitária de difamação contra aqueles poucos cientistas independentes que ousaram pesquisar transgênicos e encontraram indícios de efeitos preocupantes na saúde animal, como cânceres.

Os muitos impactos de longo prazo ao meio ambiente são igualmente minimizados, conformando-se os cientistas em exigir que os plantios respeitem distâncias bastante exíguas. A

Gomes, C, Decisões Conflitivas na Liberação dos Transgênicos no Brasil, São Paulo Perspectiva, nr.18, SP, 2004; Santos, L.G.dos, Os Biotecnólogos Brasileiros em Face da Sócio e da Biodiversidade, in Novos Estudos Cebrap, nr.78, SP, julho 2007. 
relação entre o plantio de transgênicos e o aumento do uso de agrotóxicos a eles associados também é considerada como assunto que está fora de sua responsabilidade, cabendo não a eles, dizem nossos cientistas responsáveis pela biossegurança, mas a outros órgãos, os encarregados do controle do emprego de agrotóxicos, examinar o assunto. Fatia-se assim, em uma análise cartesiana, o conjunto dos elementos que funcionam entrosadamente na natureza: genes, organismos e ecossistemas. Conclui-se a partir do laboratório, o que ocorrerá no planeta: a partir de meses, o que deverá ocorrer em décadas ou séculos. Enfim, a pesquisa científica requerida é desenhada para que não se encontre nada. E caso se encontre, que este resultado seja considerado como "não significativo".

Não é de estranhar, portanto, que após mais de 20 anos da disseminação massiva do agrotóxico Glifosato, o princípio ativo do herbicida mais usado no planeta em associação com a soja e o milho transgênico da Monsanto, alarmes finalmente soem aqui e ali. O International Agency for Research on Cancer - IARC, anunciou recentemente que o glifosato é cancerígeno para animais e provavelmente para seres humanos ${ }^{11}$. O Instituto Nacional do Câncer - INCA, considerou que o aumento exponencial de cânceres no Brasil estaria relacionado ao aumento do consumo de agrotóxicos, e em especial ao Glifosato, associado a plantas transgênicas ${ }^{12}$. Correm os lobistas das transnacionais de biotecnologia para extrair desmentidos ou encomendar pesquisas desenhadas para não encontrar nada junto a instituições que costumam receber financiamentos dessas empresas ou que são mais flexíveis a pressões políticas, como a recente declaração da FAO/OMS, argumentando que o glifosato não poderia ser cancerígeno para humanos, "devido ao modo como ele é empregado".

Tampouco do ponto de vista ambiental são exigidas as pesquisas necessárias, bem como são ignorados os sinais enviados pela natureza. No México, país de origem da domesticação do milho, encontrou-se milho transgênico no planalto central, embora até hoje o México não tenha autorizado o seu plantio. Acontece que a importação de milho transgênico dos EUA para ração animal não é capaz de impedir que grãos caídos na terra germinem e mais tarde troquem material genético com outros ${ }^{13}$. A Sindrome do colapso das colmeias, que tem levado ao desaparecimento súbito de abelhas é atribuída à intoxicação com agrotóxicos e não se deve excluir que alguns deles estejam associados aos cultivos transgênicos. A alta mortalidade das borboletas monarcas

11 International Agency for Research on Cancer, WHO, LARC Monographs Volume 12: evaluation of five organophosphate insecticides and herbicides, 20 March, 2015.

12 INCA, Ministério da Saúde: Posicionamento do INCA - José Alencar Gomes da Silva - acerca dos agrotóxicos, nr. 010.

13 Price and Cotter, The GM Contamination Register: a review of record contamination incidents associated with genetically modified organisms (GMOs) 1997-2013. International Journal of Food Contamination, 2014, 1.5. 
também pode ser decorrente de agrotóxicos associados aos transgênicos ${ }^{14}$ e assim é possível que estejamos solapando o patrimônio agrobiodiverso que os povos que consideramos "primitivos" nos deixaram e estejamos semeando um mundo estéril e monótono, onde apenas crescem e vicejam as ervas invasoras e as pragas que nele conseguirão sobreviver.

Quando, contudo, se exige a aplicação do Princípio da Precaução, empresas, cientistas e governos argumentam à boca pequena que ele impede o progresso da ciência e que essa, além disso, é neutra e busca apenas a verdade. Tudo, portanto, que Jonas com tanta propriedade criticou no discurso científico que crê em uma ciência sem interesses e livre de problemas éticos, está presente no debate sobre os transgênicos e é preciso dizer, de forma bem mais concreta $e$ generalizada, do que os seus temores em relação às manipulações com o corpo e a mente da nossa espécie.

Pois enquanto ainda discutimos e enfrentamos muita resistência das sociedades em relação a um cartão verde para a clonagem humana ou para a reprodução assistida por meio da manipulação dos genomas, no caso dos transgênicos eles já estão no nosso prato de comida, nos nossos campos e florestas, progredindo insidiosamente à sombra de autoridades, cientistas e empresas em uma associação altamente perversa.

Em suma, é preciso convocar o Princípio Responsabilidade com urgência, nos órgãos públicos que decidem sobre nossa biossegurança como a CTNBio e nos demais órgãos semelhantes de outros países, pois eles já estão decidindo o destino da humanidade, sem consultá-lo. Precisamos de Hans Jonas urgentemente na Biossegurança.

14___ Transgênicos podem afetar borboleta monarca - Ambientebrasil

noticias.ambientebrasil.com.br/.../72873-transgenicos-podem-afetar-borboleta-monar... 